\title{
PERAN GENDER PADA SIKLUS MANAJEMEN BENCANA DI SEKTOR SOSIAL EKONOMI RUMAH TANGGA TANI (BENCANA ALAM GEMPABUMI DAN LETUSAN GUNUNGAPI)
}

\author{
Dina Ruslanjari, Dian Indira Wahyunita, dan Resi Sadewa Permana \\ Magister Manajemen Bencana \\ Sekolah Pascasarjana Universitas Gadjah Mada \\ Email: dienarus@ugm.ac.id
}

\begin{abstract}
The earthquake disaster in 2006 and the eruption of Merapi Volcano in 2010 have a different impact on the community activities in the province of Yogyakarta. The aims of this research are: (1) to analyze the role of gender based on differences in the characteristics of the Merapi eruption in Sleman and Bantul earthquakes; (2) to find the socio-economic variables which influence toward the role of gender in the characteristics of the Merapi eruption in Sleman and Bantul earthquakes.

This research is using quantitative and qualitative methods. The research population is farming communities who live in the Padasan Sub-village of Sleman District and Serut Sub-village of Bantul District. Sampling technique is purposive. Data collection techniques are survey method, in-depth interview, and review of literature. Descriptive analysis was used to analyze the percentage of gender roles. Regression analysis was used to determine the variables that affect the gender role in social and economic.

The results of the descriptive analysis show that there are similarities and differences in roles between men and women in the Serut Sub-village of Bantul District and Padasan Sub-village of Sleman District despite have a different disaster. Women in the daily cycle spent more time at home during days and nights to do housework. The results of regression analysis show that there is no influence of age, education, and income to the women role in the earthquake disaster in Serut Sub-village of Bantul District and volcano eruption in Padasan Sub-village of Sleman District.
\end{abstract}

Keywords: Disasters; Gender; Role; Socio-economic.

\begin{abstract}
ABSTRAK
Bencana gempabumi pada tahun 2006 dan bencana erupsi Gunungapi Merapi tahun 2010 mempunyai dampak yang berbeda terhadap aktivitas masyarakat di Provinsi Daerah Istimewa Yogyakarta. Penelitian ini bertujuan untuk: (1) menganalisis sejauh mana peran gender berdasarkan perbedaan karakteristik bencana erupsi Merapi di Sleman dan gempabumi di Bantul; (2) menemukan variabelvariabel yang paling berpengaruh terhadap peran perempuan pada bencana erupsi Merapi di Sleman dan gempabumi di Bantul.

Penelitian ini merupakan penelitian dengan menggunakan metode kuantitatif dan kualitatif. Populasi penelitian berasal dari masyarakat petani yang tinggal di Dusun Padasan Kabupaten Sleman dan di Dusun Serut Kabupaten Bantul. Teknik penentuan sampel dilakukan secara purposive. Teknik pengumpulan data dengan menggunakan metode survei, wawancara mendalam dan kajian literatur. Analisis deskriptif digunakan untuk menganalisis persentase peran gender. Analisis regresi digunakan untuk mengetahui variabel yang berpengaruh terhadap peran perempuan dalam sosial dan ekonomi.
\end{abstract}


Hasil penelitian menunjukkan bahwa terdapat kesamaan dan perbedaan peran antara lakilaki dan perempuan di Dusun Serut Kabupaten Bantul dan Dusun Padasan Kabupaten Sleman. Di Dusun Padasan, semua laki-laki bekerja, sebagian perempuan tidak bekerja, hanya mengurus rumah tangga. Di Dusun Serut sebagian perempuan memiliki peran ganda dan berlebihan, bekerja menambah pendapatan keluarga dan melakukan kegiatan rumah tangga. Hasil dari analisis regresi menunjukkan bahwa tidak terdapat pengaruh dari variabel umur, pendidikan, dan penghasilan terhadap peran perempuan dalam bencana gempabumi di Dusun Serut Kabupaten Bantul dan bencana erupsi gunungapi di Dusun Padasan kabupaten Sleman.

Kata Kunci: Bencana; Gender; Peran, Sosial ekonomi.

\section{PENGANTAR}

Kejadian gempabumi pada tahun 2006 dan letusan Gunungapi Merapi tahun 2010 yang terjadi di Provinsi DI Yogyakarta, menjadi catatan penting bagi sejarah bencana Indonesia. Kedua bencana alam yang terjadi mempunyai dampak yang berbeda terhadap penghidupan masing-masing individu dan kelompok masyarakat. Hal tersebut tergantung kepada kapasitas serta tingkat kerentanan yang dimilikinya. Selain dua hal tersebut, juga dipengaruhi oleh fungsi, peran, dan tanggung jawab individu dari jenis kelamin berbeda atau disebut gender.

Perbedaan sosial dan budaya yang tercermin dalam kearifan lokal dipengaruhi oleh lingkungan fisik wilayah tempat tinggal, tentunya juga perbedaan karakteristik masyarakat terdapat di dua dusun tersebut. Dusun Padasan Kabupaten Sleman terletak di lereng bawah dari Gunungapi Merapi sehingga riskan terhadap ancaman letusan gunung. Sdangkan Dusun Serut Kabupaten Bantul yang berada pada kawasan dataran cenderung mempunyai ancaman bencana gempabumi.

Kedua kelompok masyarakat di wilayah berbeda tersebut mempunyai mata pencaharian dalam bidang pertanian. Efek dari abu hasil erupsi Gunungapi Merapi dapat menyuburkan tanah, sehingga aktivitas pertanian tidak tertumpu pada beberapa jenis pertanian palawija saja, namun juga sangat cocok untuk berbagai jenis sayuran. Lain halnya dengan masyarakat petani di Bantul yang wilayahnya dikenal sebagai wilayah dataran aluvial. Dari sistem irigasi mungkin tidak ditemukan kesulitan karena Bantul banyak dialiri sungai-sungai yang cukup besar, namun dalam pemilihan tanaman pertanian kawasan dengan karakteristik dataran dan memiliki suhu tinggi seperti Bantul tidak dapat ditanami berbagai jenis tanaman maupun sayuran, hanya beberapa tanaman saja yang mampu beradaptasi dengan iklim mikro wilayah setempat seperti padi, kedelai, kacang tanah dan jagung. (Ruslanjari, 2013).

Dalam kaitannya dengan agrikultural, perempuan dirugikan karena perbedaaan gender dalam akses pada sumberdaya (Fischer dan Qaim, 2012: 441). Perempuan jarang mendapatkan akses langsung atau kontrol untuk mengelola sumberdaya (Karami dan Mansoorabadi, 2008: 884). Dalam kaitannya dalam bencana, hubungan gender merupakan bagian dari pengalaman manusia tentang bencana dan dalam beberapa keadaan mengacu pada penolakan hak perempuan dalam keadaan bencana (Enarson, et. al., 2007: 130).

Dalam kajian mengenai peran gender dalam usaha tani di Kabupaten Bantul maupun Kabupaten Sleman dalam penanggulangan bencana dapat menjadi salah satu gambaran bahwa keterbatasan ruang gerak tidak mengurungkan perempuan untuk memaksimalkan fungsinya dalam siklus manajemen bencana, yaitu pra-tanggap daruratpasca bencana. Perumusan masalah dalam penelitian ini yaitu: a) bagaimanakah peran gender dalam siklus penanggulangan bencana pada sektor sosial ekonomi masyarakat tani berbasis gender pada gempabumi Bantul dan erupsi Merapi Sleman di Daerah Istimewa Yogyakarta serta b) Variabel-variabel apakah yang paling berpengaruh terhadap peran perempuan dalam pada gempabumi di Dusun Serut Bantul dan erupsi gunung api Merapi di Dusun Pdanaan Sleman Provinsi Daerah Istimewa Yogyakarta. Atas dasar permasalahan tersebut, disusun tujuan dari penelitian ini: (1) menganalisis sejauh mana peran gender pada 
bencana erupsi gunung api Merapi di Dusun Pdanaan Sleman dan gempabumi di Dusun Serut Bantul; (2) menemukan variabel-variabel sosial ekonomi yang paling berpengaruh terhadap peran gender pada bencana erupsi gunung api Merapi di Dusun Pdanaan Sleman dan gempabumi di Dusun Serut Bantul.

Hasil dari penelitian ini diharapkan dapat bermanfaat dalam pengembangan ilmu pengetahuan terutama mengenai peran gender dalam siklus manajemen bencana. Hasil dari penelitian ini juga diharapkan mampu menjadi rekomendasi untuk program pemerintah terkait maupun untuk masyarakat terkait guna peningkatan aspek sosial ekonomi pada kawasan rawan bencana.

Penelitian yang dilakukan oleh Elizabeth (2008) mengangkat tema "Peran Ganda Perempuan Tani dalam Mencapai Ketahanan Pangan". Penelitian ini menekankan pada pencapaian ketahanan pangan dengan mengikutsertakan aspek gender di beberapa hal terkait dengan usaha tani. Perempuan tani dipandang memiliki posisi yang strategis dan akan sangat membantu apabila diberikan wadah yang tepat sesuai dengan kemampuan dan pengetahuannya. Hasil dari penelitian Elizabeth adalah peran ganda perempuan tani sangat strategis dalam peningkatan produktivitas usahatani dan berpotensi untuk meningkatkan pendapatan dan ketahanan pangan menuju kesejahteraan rumah tangga petani di perdesaan. Perempuan tani berpeluang dan mampu berperan sebagai mitra kerja penyuluh dalam proses alih teknologi pertanian di perdesaan

Fatimah (2010) dalam "Gender Mainstreaming dalam Pengurangan Risiko Bencana Studi Kasus Bencana Gempabumi di Bantul". Aspek yang ditekankan dalam penelitian ini adalah tingkat kerentanan dari seorang perempuan dengan pola aktivitasnya yang kebanyakan dihabiskan sebagai ibu rumah tangga memiliki tingkat kerentanan yang lebih tinggi daripada anggota keluarga lain. Hasil yang diperoleh dari penelitian Fatimah adalah terbukti bahwa perempuan dan anak-anak pada umumnya memiliki tingkat kerentanan tinggi di beberapa aspek, baik aspek kesehatan, sosial ekonomi, maupun politik.

Beberapa variabel dari penelitian ini dapat dijadikan pembeda dan suatu inovasi baru dari penelitian sebelumnya yakni menggambarkan aktivitas gender khususnya perempuan tani pada fase penanggulangan bencana dalam perspektif keruangan. Perbedaan pola keruangan serta perbedaan ancaman bencana memberikan karakteristik tersendiri di tiap wilayah dalam aktivitas kesehariannya.

Gender merupakan peran, fungsi, dan tanggung jawab antara laki-laki dan perempuan yang merupakan hasil dari konstruksi sosial dan dapat berubah sesuai dengan perkembangan jaman (BKKBN, 2007: 7). Seks merujuk pada aspek biologis antara perempuan dan lakilaki (Pryzgoda dan Chrisler, 2000: 554). Tong, et. al. (2016: 952) juga menambahkan bahwa gender juga menunjukkan kepada status, tanggung jawab, hak, dan partisipasi dalam semua area dan semua level dari hubungan sosial, yang didalamnya termasuk manajemen sumberdaya, kewenangan publik, dan penentu kebijakan. Hal ini menunjukkan bahwa gender merupakan suatu budaya dan merupakan istilah untuk laki-laki dan perempuan sebagai kelompok sosial (APA, 2010: 71; Muehlenhard dan Peterson, 2011: 798). Alston (2013: 8) juga menambahkan bahwa gender juga merupakan interaksi secara historis, sosial, budaya dan ikatan kontekstual.

BKKBN (2007: 17-20) menjelaskan bahwa teori tentang gender terbagi menjadi tiga, yakni teori nurture, teori nature, dan teori equilibrium. Teori nurture menjelaskan bahwa perbedaan perempuan dan laki-laki pada hakekatnya adalah hasil konstruksi sosial budaya sehingga menghasilkan peran dan tugas yang berbeda. Teori nature menjelaskan bahwa perbedaan perempuan dan laki-laki adalah kodrat sehingga tidak dapat berubah dan bersifat universal. Teori equilibrium menekankan pada konsep kemitraan dan keharmonisan dalam hubungan antara perempuan dan laki-laki. Pdanangan ini tidak mempertentangkan antara kaum perempuan dan laki-laki karena keduanya harus bekerjasama dalam kemitraan 
dan keharmonisan dalam kehidupan berkeluarga, bermasyarakat, dan berbangsa.

Sistem patriarkat yang telah lama berlangsung dalam kehidupan masyarakat telah memberikan keuntungan lebih pada lakilaki. Sementara itu, teori gender menetapkan pola baku, yakni peran yang berbeda antara laki-laki dan perempuan menurut persepsi masyarakat setempat (Partini, 2013: 25). Apabila antara laki-laki dan perempuan dalam unit keluarga dapat melakukan kerja sama yang baik, mereka dapat bersama-sama bekerja dan mengembangkannya untuk kepentingan keluarga (Partini, 2013: 29).

UU No 24 tahun 2007 tentang penanggulangan bencana menyebutkan bahwa "Bencana adalah peristiwa atau rangkaian peristiwa yang mengancam dan mengganggu kehidupan dan penghidupan masyarakat yang disebabkan, baik oleh faktor alam dan/ atau faktor nonalam maupun faktor manusia sehingga mengakibatkan timbulnya korban jiwa manusia, kerusakan lingkungan, kerugian harta benda, dan dampak psikologis."

Gempabumi merupakan bencana yang sering terjadi di Indonesia, yang disebabkan oleh interaksi lempeng tektonik dan letusan gunung api. Gempabumi adalah getaran atau guncangan yang terjadi di permukaan bumi akibat pelepasan energi dari dalam secara tibatiba yang menciptakan gelombang seismik. Dampak gempabumi merupakan salah satu kejadian bencana yang belum dapat diprediksi kapan akan terjadinya, namun memberikan dampak yang luar biasa. Yogyakarta Media Center, 7 Juni 2006, dalam BAPPENAS (2006: 3) mencatat kejadian gempabumi di Yogyakarta dan Jawa Tengah tahun 2006 telah mengakibatkan korban meninggal sebesar 5.716 jiwa dan korban luka-luka 37.927 orang. BAPPENAS (2006: 14) memperkirakan bahwa kerugian total yang diakibatkan oleh bencana gempabumi tersebut mencapai sekitar 29,1 trilyun rupiah.

Erupsi gunung api adalah proses keluarnya magma dan atau gas dari dalam bumi ke permukaan berupa letusan yang menghasilkan bahan lepas berbagai ukuran atau leleran yang menghasilkan lava/ leleran batu pijar. Picquout, et. al. (2013: 367) menyebutkan bahwa erupsi Gunung Merapi pada tahun 2010 telah mengakibatkan efek pada sektor geografi dan sektor ekonomi. Aliran piroklastik mencapai $4 \mathrm{~km}$ ke arah utara, $7 \mathrm{~km}$ ke arah barat, dan $16 \mathrm{~km}$ ke arah selatan. Bom dari ledakan mencapai $4 \mathrm{~km}$ ke segala arah, disertai dengan banyaknya debu dan gas yang dirilis ke atmosfer. Berdasarkan data yang dihimpun Dinas Kesehatan Kabupaten Sleman 2010, jumlah korban meninggal akibat bencana erupsi Gunung Merapi mencapai 270 orang. Muhammad (2015: 133) juga menyebutkan bahwa Kabupaten Sleman merupakan daerah yang paling banyak terkena dampak bencana, kemudian disusul oleh Kabupaten Magelang, Kabupaten Klaten, dan Kabupaten Boyolali.

Penelitian dilakukan di lereng selatan Gunung api Merapi, pada lereng bawah dan dataran aluvial. Lereng bawah dilakukan pada Dusun Padasan, Desa Pakembinangun, Kecamatan Pakem, Kabupaten Sleman. Pada dataran aluvial dilakukan pada Dusun Serut Desa Palbapang, Kecamatan Pandak, Kabupaten Bantul. Kawasan tersebut merupakan kawasan yang rawan bencana. Kedua lokasi tersebut merupakan wilayah yang berpotensi tinggi terhadap pertanian. Penelitian dilaksanakan pada bulan Mei Agustus 2014. Metode yang digunakan dalam penelitian ini yaitu metode kuantitatif dan kualitatif.

Populasi berasal dari masyarakat petani yang tinggal di Dusun Padasan Kabupaten Sleman dan di Dusun Serut Kabupaten Bantul Provinsi Daerah Istimewa Yogyakarta. Dari dua desa tersebut diambil anggota kelompok tani setempat dan yang terdampak bencana. Total populasi penelitian pada Dusun Padasan Kabupaten Sleman dan Dusun Serut Kabupaten Bantul adalah 127 anggota kelompok usaha tani padi. Populasi penelitian di Dusun Padasan Kabupaten Sleman adalah 57 anggota kelompok usaha tani padi yang terbagi menjadi 27 anggota kelompok petani perempuan dan 30 anggota kelompok petani pria. Populasi penelitian di Dusun Serut Kabupaten Bantul adalah 70 anggota kelompok usaha tani padi yang terbagi menjadi 30 anggota kelompok 
petani perempuan dan 40 anggota kelompok petani pria.

Jenis data dan variabel disajikan dalam Tabel 1. Siklus aktivitas laki-laki dan perempuan, dibagi dalam aktivitas pagi, siang dan sore-malam. Aktivitas pagi yakni antara jam 5.01-11.00. Aktivitas siang yakni antara jam 11.01-16.00. Aktivitas sore-malam yakni antara jam 16.01-22.00. Persentase aktivitas: menggambarkan jumlah perempuan dengan laki-laki dalam melakukan satu kegiatan.

Tabel 1. Jenis Data, Indikator serta Variabel

\begin{tabular}{l|l|l}
\hline \multicolumn{1}{c|}{ Indikator } & \multicolumn{1}{c}{ Variabel } & \multicolumn{1}{c}{ Analisis Data } \\
\hline $\begin{array}{l}\text { Peran Gender dalam aspek sosial } \\
\text { ekonomi }\end{array}$ & $\begin{array}{l}\text { Aktivitas laki-laki dan perempuan } \\
\text { dalam aspek sosial ekonomi sesuai } \\
\text { dengan siklus harian baik pra - tanggap } \\
\text { darurat - pasca bencana }\end{array}$ & $\begin{array}{l}\text { Kuantitatif dan } \\
\text { kualitatif }\end{array}$ \\
\hline $\begin{array}{l}\text { Faktor-faktor yang berpengaruh } \\
\text { terhadap peran perempuan }\end{array}$ & $\begin{array}{l}\text { 1. Pendapatan } \\
\text { 2. Umur } \\
\text { 3. Tingkat Pendidikan }\end{array}$ & Kuantitatif \\
\hline
\end{tabular}

Sumber: Peneliti, 2017

Pengumpulan data dilakukan dengan cara: a) Sampling, pengambilan sampel rumah tangga tani secara purposive; b) survey, kegiatan survei adalah melihat secara langsung potensi dan kondisi fisik, sosial, dan ekonomi masyarakat dengan menggunakan kuesioner; c) wawancara mendalam; dan d) kajian literatur dari berbagai jurnal.

Data yang diperloleh dianalisis dengan dua pendekatan di bawah ini.

1) Analisis dengan menggunakan tabel siklus harian yang berisi mengenai persentase peran gender dengan menggunakan analisis deskriptif.

2) Analisis dengan regresi guna mengetahui variabel-variabel yang berpengaruh terhadap peran perempuan dalam sosial dan ekonomi.

\section{PEMBAHASAN \\ DUSUN SERUT \\ Siklus Harian pada Prabencana}

Siklus harian merupakan suatu aktivitas yang dilakukan sehari-hari di mana melalui kegiatan dalam siklus harian tersebut dapat diketahui peran dari masing-masing individu dalam melakukan aktivitasnya sehari-hari. Siklus harian pra bencana pada pagi hari baik laki-laki maupun perempuan di Dusun Serut disajikan dalam Gambar 1.

Gambar 1. Siklus Harian Pra Bencana Pada Pagi Hari di Dusun Serut

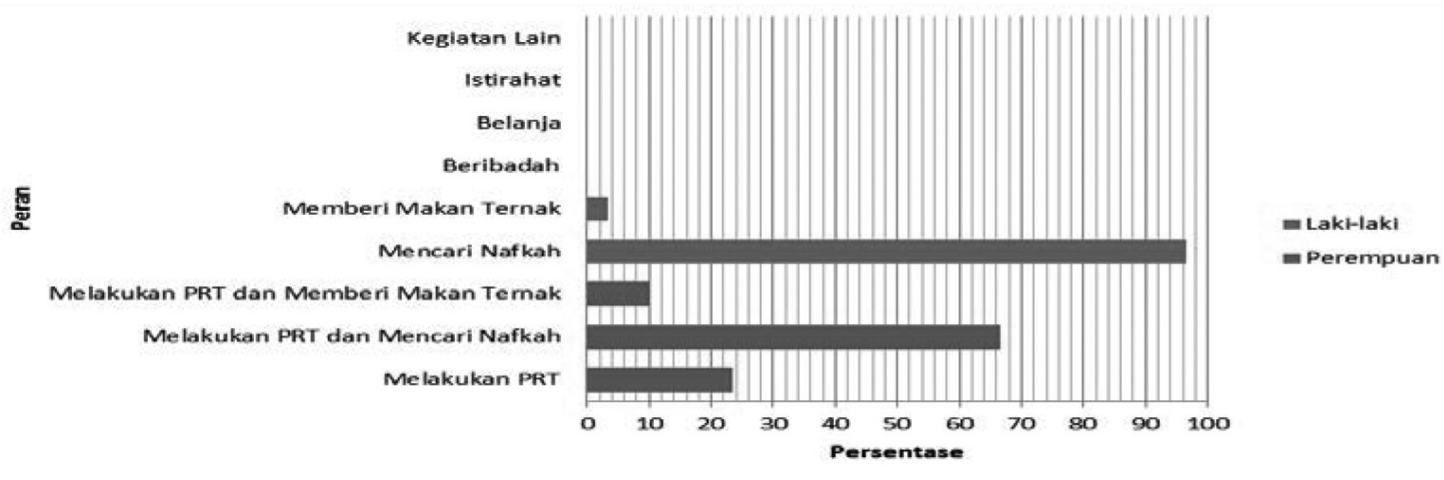

Gambar 1. Siklus Harian Pra Bencana Pada Pagi Hari di Dusun Serut Sumber: Analisis data primer 2014 
Pada pagi hari kaum laki-laki di Dusun Serut lebih banyak menghabiskan waktunya di luar rumah untuk mencari nafkah pada sektor pertanian maupun di luar sektor pertanian, yaitu berdagang dan buruh bangunan. Wanita yang bekerja sebagai buruh bangunan sangat sedikit. Hal tersebut sejalan dengan pernyataan Marioka, 1983, dalam Partini (2013: 27) yang menjelaskan dugaan budaya patriarkat yang mempengaruhi pola perekrutan tenaga kerja dan persepsi bahwa pekerja perempuan kurang produktif dibdaningkan dengan lakilaki. Di sisi lain perempuan sebagai ibu rumah tangga juga mencari nafkah guna membantu mencukupi kebutuhan keluarganya.

Ada dominasi peran ganda pada pihak perempuan bahwa selain melakukan aktivitas sebagai ibu rumah tangga, kebanyakan dari mereka melakukan tugas membantu mencari nafkah, mengurus rumah tangga dan memberi makan ternak. Sebesar 3,33\% jumlah laki-laki yang membantu melakukan pekerjaan rumah tangga. Siklus harian pra bencana pada siang hari baik laki-laki maupun perempuan di Dusun Serut disajikan dalam Gambar 2.

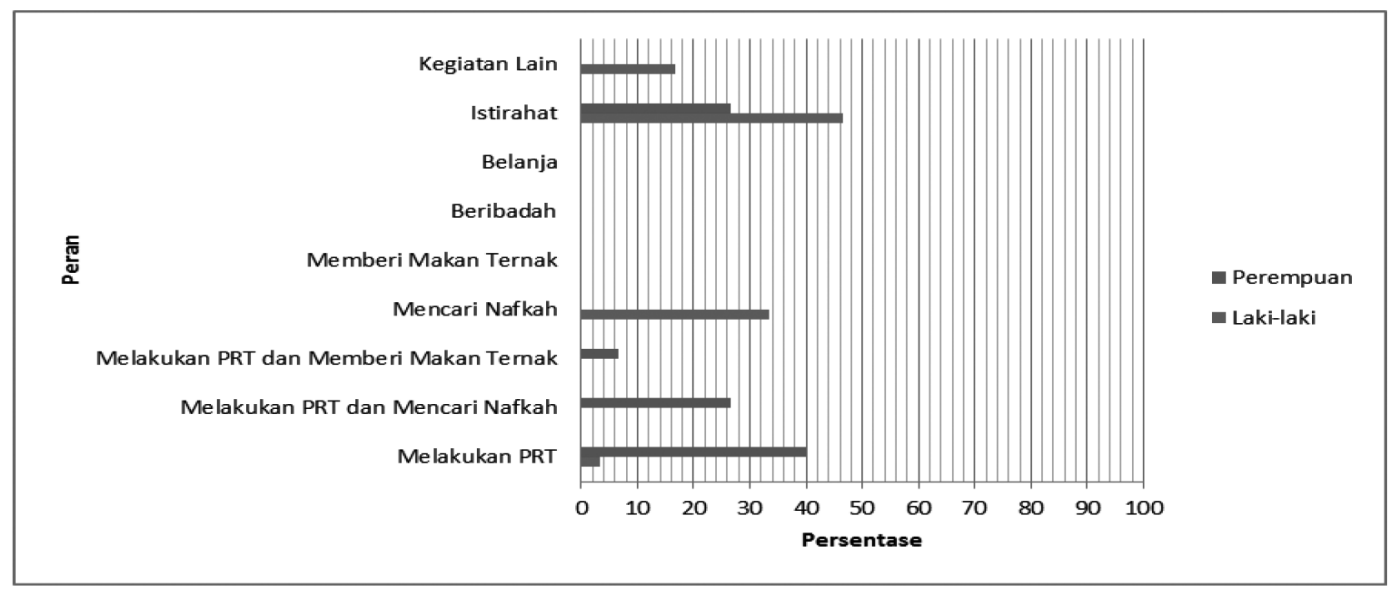

Gambar 2. Siklus Harian Pra Bencana Pada Siang Hari di Dusun Serut Sumber: Analisis Data Primer 2014

Peran perempuan di Dusun Serut memiliki tanggung jawab ganda hampir setengah dari jumlah responden, berarti perempuan memiliki peran penting dalam memberikan danil bagi pendapatan keluarga.



Gambar 3. Siklus Harian Pra Bencana Pada Malam Hari di Dusun Serut Sumber: Analisis Data Primer 2014 
Pada malam hari perempuan dan lakilaki beristirahat, juga melakukan kegiatan beribadah. Dalam seminggu diadakan pertemuan anggota kelompok tani sebanyak tiga kali, selain itu juga diadakan pengajian pada setiap Kamis malam. Siklus harian pra bencana pada malam hari baik laki-laki maupun perempuan di Dusun Serut disajikan dalam Gambar 3.

\section{Peran Gender pada Fase Tanggap Darurat}

Pada tanggal 27 Mei 2006 Dusun Serut dildana bencana gempabumi yang berdampak pada aspek fisik maupun sosial ekonomi. Peran laki-laki dan Perempuan dalam fase tangap darurat ini mempunyai jumlah yang hampir sama, yaitu dalam kegiatan menyelamatkan diri, walaupun sebagian tidak mengungsi di Posko, memilih tinggal di rumah sanak keluarganya. Dari wawancara mendalam dengan responden diketahui bahwa separuh kaum perempuan mendorong keluarga mengungsi di tempat sanak saudaranya, karena dianggap lebih nyaman. Peran gender pada tanggap darurat bencana ditunjukkan oleh Gambar 4.



Gambar 4. Peran Gender Pada Tanggap Darurat Bencana di Dusun Serut Sumber: Analisis data Primer 2013

Perempuan masih dianggap sebagai mahluk yang memiliki risiko tinggi selama bencana atau bahkan dianggap sebagai kelompok rentan, sehingga akses yang dimiliki perempuan menjadi terbatas. Terdapat ketimpangan yang kuat dalam hubungan gender antara laki-laki dan perempuan, pihak perempuan cenderung dirugikan (UNISDR, 2009: 3). Ketimpangan gender terekspos saat terjadinya bencana (UNISDR, 2009: 2; Reyes dan Lu, 2016: 162).

\section{Peran Gender Pada Fase Pascabencana}

Pada fase pasca bencana, pada umumnya seluruh masyarakat yang terdampak bencana melakukan berbagai kegiatan yang bertujuan untuk memulihkan kondisi sosial maupun ekonomi rumah tangga. Sebagian besar kaum laki-laki kembali meneruskan bekerja di sektor pertanian yang sempat terbengkalai akibat bencana, sisanya di sektor bangunan dan berdagang. Kaum laki-laki tidak mengandalkan bantuan dari pemerintah. Kaum perempuan hanya 3\% saja yang mengandalkan bantuan dari pemerintah, yaitu mendapat bantuan jadup (jatah hidup), berupa beras dan lauk pauk dalam 1 bulan pada masa tanggap darurat yang ditetapkan dalam 30 hari. Peran gender pada pasca bencana ditunjukkan oleh Gambar 5 . 


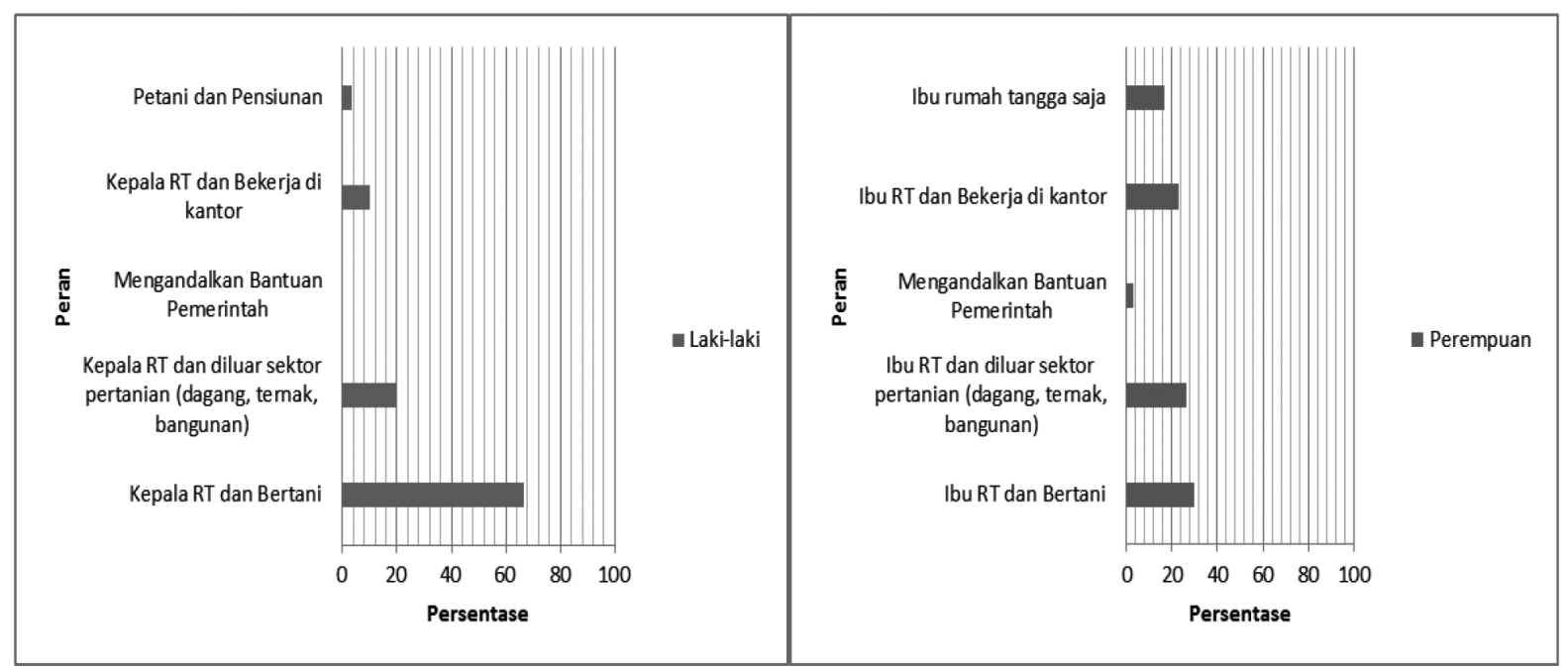

Gambar 5. Peran Gender Pada Pasca Bencana di Dusun Serut Sumber: Analisis Data Primer 2013

Laki-laki pada pascabencana ini lebih peduli terhadap urusan rumah tangga dibanding sebelum bencana karena sedikitnya pekerjaan di sawah (tinggal menunggu masa panen tiba). Sepertiga kaum perempuan memilih untuk kembali bertani, seperti menyiangi tegalan dan sawah. Selebihnya berdagang berbagai kebutuhan sehari-hari di pasar. Ada tiga perempuan yang bekerja sebagai buruh bangunan, namun $7 \%$ memilih di rumah untuk mengurus keluarga dan rumah tangga.

\section{Dusun Padasan \\ Siklus Harian pada Pra Bencana}

Siklus harian pra bencana baik pria maupun perempuan di Dusun Padasan disajikan dalam Gambar 6.

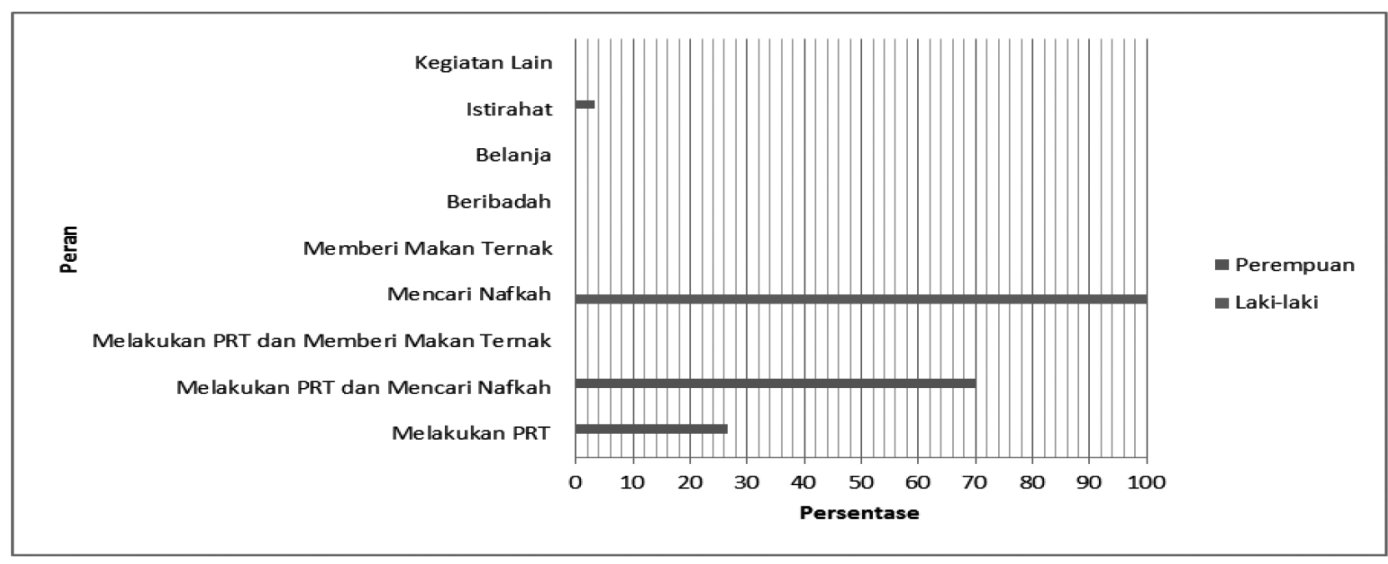

Gambar 6. Siklus Harian Pra Bencana Pada Pagi Hari di Dusun Padasan Sumber: Analisis Data Primer 2014

Di desa Padasan, semua laki-laki bekerja sebagai petani dan tidak melakukan pekerjaan rumah tangga, semua pekerjaan rumah tangga dilakukan oleh kaum perempuan. Pada pagi sebagian kecil perempuan juga membantu bekerja mencari nafkah. Siklus harian pada siang hari ditunjukkan pada Gambar 7. 


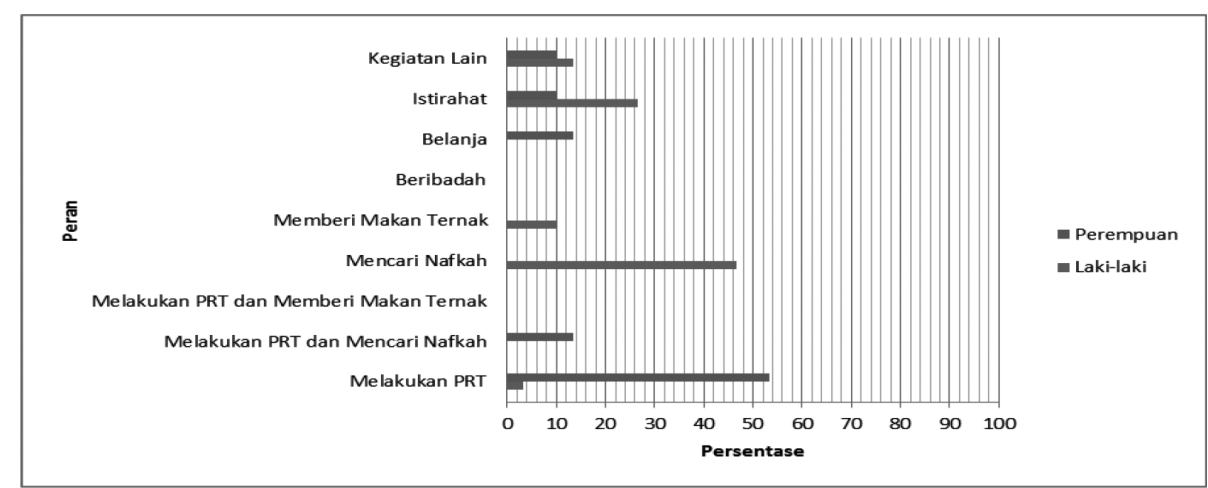

Gambar 7. Siklus Harian Pra Bencana Pada Siang Hari di Dusun Padasan Sumber: Analisis Data Primer 2014

Siklus harian pada siang hari aktivitas utama yang dilakukan oleh separuh lakilaki. Separuh kaum perempuan melakukan pekerjaan rumah tangga di rumah. Pada malam hari, baik dari pria maupun perempuan memilih untuk tetap tinggal di rumah, melakukan ibadah dan beristirahat. Keduanya memiliki jumlah separuh dari sampel. Siklus harian pra bencana pada malam hari ditunjukkan oleh Gambar 8.

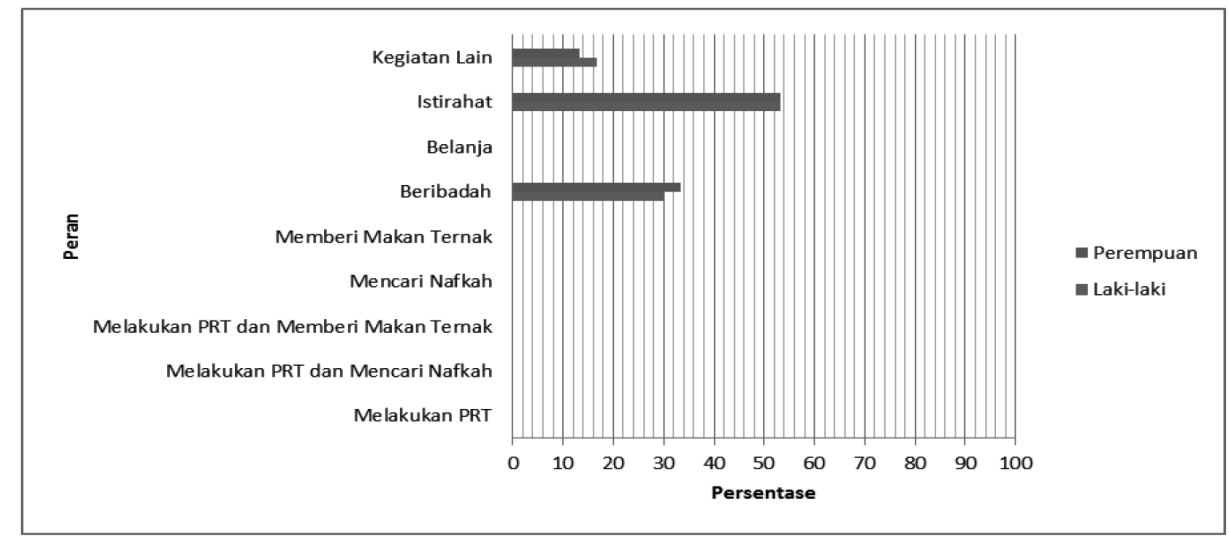

Gambar 8. Siklus Harian Prabencana Pada Malam Hari di Dusun Padasan Sumber: Analisis Data Primer 2014

\section{Peran Gender Pada Fase Tanggap Darurat masing individu pada fase tanggap darurat} Pada Gambar 9 tergambarkan aktivitasaktivitas utama yang dilakukan oleh masing-

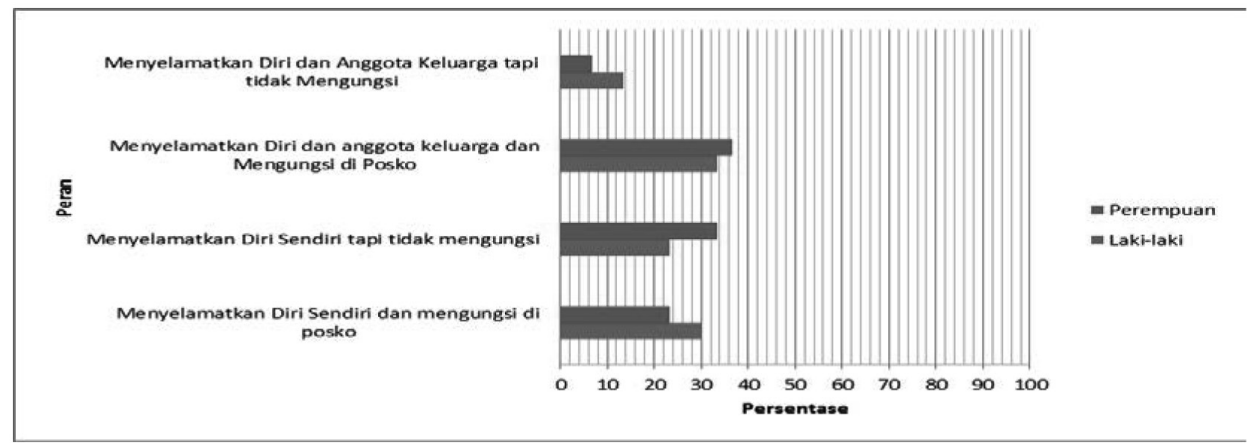

Gambar 9. Peran Gender pada Fase Tanggap Darurat Sumber: Analisis data primer 2012 
Aktivitas utama yang dilakukan pada fase tanggap darurat adalah menyelamatkan diri dan anggota keluarga untuk mengungsi di posko, yang dilakukan oleh sepertiga jumlah laki-laki dan perempuan. Sebanyak 33\% perempuan tidak mengungsi, begitu pula $23 \%$ perempuan melakukan hal yang sama karena mempunyai persepsi bahwa abu vulkanik tidak membahayakan bagi kehidupannya. Selain akitivitas utama yakni pindah dari rumah tempat tinggalnya ke posko, terdapat pula beberapa individu maupun keluarganya yang menyelamatkan diri dan memilih untuk tinggal di luar kota atau di tempat sanak saudara.

\section{Peran Gender pada Fase Pascabencana}

Peran Gender pada pascabencana yaitu memulihkan kondisi sosial ekonomi. Berikut merupakan gambaran peran gender pasca bencana yang tergambar pada Gambar 10.

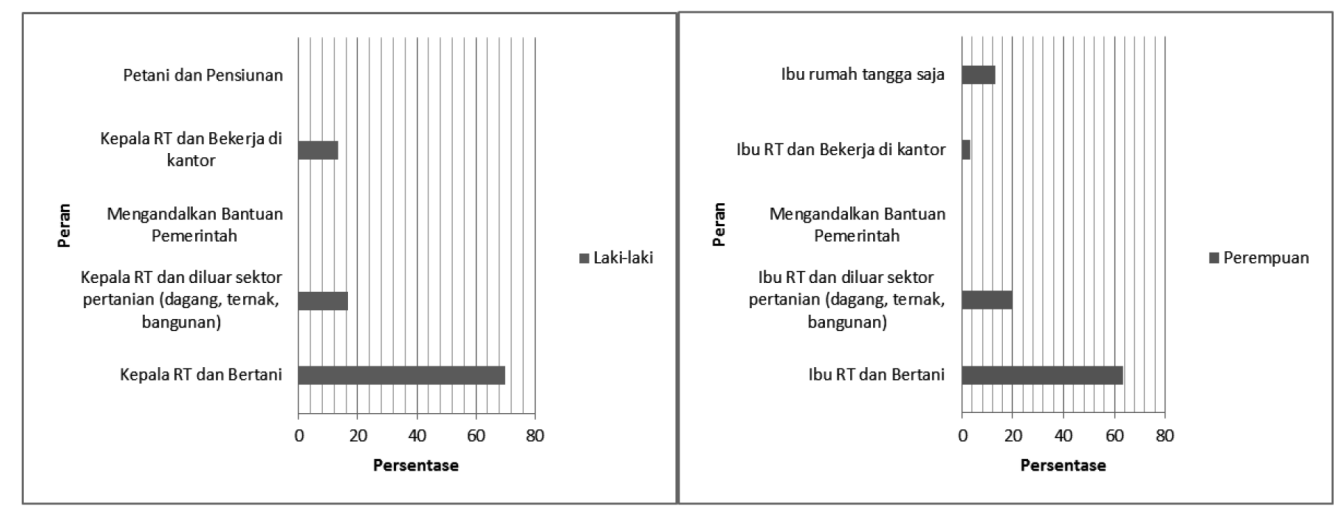

Gambar 10. Peran Gender Pada Fase Pasca Bencana Sumber: Analisis Data Primer 2014

Aktivitas yang banyak dipilih oleh kaum laki-laki maupun perempuan pasca bencana erupsi Merapi Tahun 2010 adalah mengerjakan pekerjaan lamanya, yaitu kembali pada sektor pertanian. Laki-laki dan perempuan tidak ada yang mengandalkan bantuan dari pemerintah, walaupun separuh diantaranya tinggal di posko pengungsian. Di Dusun Padasan, terdapat sebesar 15\% kaum laki-laki bekerja di kantor sebagai PNS, yaitu sebagai penyuluh lapangan di Dinas Pertanian, guru sekolah, dan pegawai kelurahan. Kaum perempuan sebesar $2 \%$ bekerja sebagai guru sekolah dasar.

\section{Faktor-Faktor Berpengaruh terhadap Peran Perempuan dalam Kebencanaan di Sektor Sosial Ekonomi}

Faktor-faktor yang berpengaruh terhadap perempuan dalam kebencanaan di sektor sosial eknomi di Dusun Serut Kabupaten Bantul, maupun di Dusun Padasan Kabupaten Sleman disajikan pada Tabel 2 dan Tabel 3.

Tabel 2. Hasil Regresi di Dusun Serut

\begin{tabular}{|c|c|c|c|c|c|c|}
\hline \multirow{2}{*}{\multicolumn{2}{|c|}{ Model }} & \multicolumn{2}{|c|}{ Unstdanardized Coefficients } & \multirow{2}{*}{\begin{tabular}{|c|} 
Stdanardized Coefficients \\
Beta \\
\end{tabular}} & \multirow[t]{2}{*}{$\mathbf{t}$} & \multirow[t]{2}{*}{ Sig } \\
\hline & & B & Std. Error & & & \\
\hline \multirow[t]{4}{*}{1} & (Constant) & 2,921 & 3,374 & & 866 & 395 \\
\hline & Umur & 021 & , 050 & ,095 & 411 & 685 \\
\hline & Pendidikan &,- 030 & 477 &,- 017 &,- 063 & ,951 \\
\hline & Penghasilan & $1,498 \mathrm{E}-6$ & ,000 & ,230 & 874 & ,390 \\
\hline \multirow[t]{3}{*}{2} & (Constant) & 2,830 & 2,988 & & 947 & 352 \\
\hline & Umur & 022 & , 047 & ,099 & 460 & 649 \\
\hline & Penghasilan & $1,439 \mathrm{E}-6$ & , 000 & ,221 & 1,021 & 316 \\
\hline
\end{tabular}




\begin{tabular}{|c|c|c|c|c|c|c|c|}
\hline \multirow{2}{*}{\multicolumn{2}{|c|}{ Model }} & \multicolumn{2}{|c|}{ Unstdanardized Coefficients } & \multirow{2}{*}{\multicolumn{2}{|c|}{\begin{tabular}{|c|} 
Stdanardized Coefficients \\
Beta \\
\end{tabular}}} & \multirow[t]{2}{*}{$t$} & \multirow[t]{2}{*}{ Sig } \\
\hline & & B & Std. Error & & & & \\
\hline \multirow[t]{2}{*}{3} & (Constant) & 4,109 & 1,078 & & & 3,813 & ,001 \\
\hline & Penghasilan & $1,124 \mathrm{E}-6$ &, 000 & ,172 & & ,926 & ,363 \\
\hline 4 & (Constant) & 5,033 & ,405 & & & 12,416 & ,000 \\
\hline a & \multicolumn{7}{|c|}{ Dependent Variable: PeranPerempuan } \\
\hline & angan & lat signifikans & are $=0,03$ & ted $R$ square & $=-0,005$ & F Hitung & , ,857 \\
\hline
\end{tabular}

Dari Tabel 2 diketahui bahwa hasil regresi dengan metode backward menunjukkan umur, pendidikan, dan penghasilan tidak

berpengaruh nyata terhadap peran perempuan dalam tiap fase bencana.

Tabel 3. Hasil Regresi di Dusun Padasan

\begin{tabular}{|c|c|c|c|c|c|c|c|}
\hline \multirow{2}{*}{\multicolumn{2}{|c|}{ Model }} & \multicolumn{2}{|c|}{ Unstdanardized Coefficients } & \multirow{2}{*}{\multicolumn{2}{|c|}{\begin{tabular}{|c|} 
Stdanardized Coefficients \\
Beta \\
\end{tabular}}} & \multirow[t]{2}{*}{$\mathbf{t}$} & \multirow[t]{2}{*}{ Sig } \\
\hline & & B & Std. Error & & & & \\
\hline \multirow[t]{4}{*}{1} & (Constant) & 4,041 & 3,914 & & & 1,033 & ,311 \\
\hline & Umur &,- 004 &, 040 &,- 025 & &,- 089 & ,930 \\
\hline & Pendidikan &,- 126 & 639 &,- 056 & &,- 198 & 845 \\
\hline & Penghasilan & 7,898E-7 & , 000 &, 342 & & 1,801 & ,083 \\
\hline \multirow[t]{3}{*}{2} & (Constant) & 3,721 & 1,525 & & & 2,440 & ,022 \\
\hline & Pendidikan &,- 084 & ,419 &,- 037 & &,- 201 & 842 \\
\hline & Penghasilan & $7,940 \mathrm{E}-7$ & , 000 & ,344 & & 1,855 & , 075 \\
\hline \multirow[t]{2}{*}{3} & (Constant) & 3,429 & 441 & & & 7,767 & ,000 \\
\hline & Penghasilan & 7,759E-7 &, 000 & ,336 & & 1,887 & ,070 \\
\hline $\mathrm{a}$ & \multicolumn{7}{|c|}{ Dependent Variable: PeranPerempuan } \\
\hline & rangan & gkat signifikar & are $=0,113$ & $R$ square & $=0,081$ & &, 560 \\
\hline
\end{tabular}

Dari Tabel 3 diketahui bahwa hasil regresi dengan metode backward menunjukkan bahwa umur, pendidikan dan penghasilan tidak ada yang berpengaruh nyata terhadap peran perempuan dalam tiap fase bencana.

Di kedua dusun menunjukkan bahwa tidak ada variabel yang signifikan terkait dengan peran perempuan dalam bencana pada aspek sosial ekonomi. Variabel tersebut yaitu umur, pendidikan, maupun penghasilan. Hal ini dikarenakan terdapat asumsi bahwa umur, pendidikan, maupun penghasilan belum bisa menjamin peran perempuan dalam aspek sosial ekonomi di bidang bencana akan berjalan dengan baik. Pembagian peran tidak dipengaruhi oleh umur, pendidikan dan penghasilan, jadi dipengaruhi oleh persepsi masyarakat atau budaya lokal. Sesuai dengan teori gender menetapkan pola baku, yakni peran yang berbeda antara laki-laki dan perempuan menurut persepsi masyarakat setempat. Perempuan yang bekerja telah menambah perannya, hal ini tidak diikuti dengan naiknya peran laki-laki dalam rumah tangga (Raporot dan Raporot, 1971 dalam Partini, 2013: 28).

Siklus keseharian perempuan seperti yang tertera pada hasil penelitian di mana perempuan lebih banyak menghabiskan waktunya di rumah dan melakukan pekerjaan rumah tangga di pagi hari dan malam hari, meskipun pada pagi hari -siang hari kaum perempuan juga mencari nafkah. Sesuai dengan Cinamon dan Rich (2002: 532) bahwa wanita 
juga mempunyai tanggung jawab terhadap keadaan rumah.

\section{Peran Perempuan dan Pria dalam Aspek Sosial Ekonomi di Dusun Serut dan Padasan}

Dalam rumah tangga masyarakat tani, ada pembagian kerja antara laki-laki dan perempuan. Laki-laki bekerja membajak sawah, mengolah lahan, sedangkan wanita menanam, menyemai dan memanen. Hal ini nampak jelas pada siklus keseharian baik antara perempuan maupun laki-laki pada fase prabencana di mana laki-laki menjalankan tugasnya sesuai dengan tanggung jawab serta kewajibannya dan begitupula dengan perempuan. Sejalan dengan Myrdal dan Klein (1956) dan Raporot dan Raporot (1971) dalam Partini, (2013: 28), yakni perempuan yang bekerja mempunyai peran ganda dengan mengkombinasikan antara peran sebagai pekerja dan peran sebagai ibu rumah tangga. Sesuai dengan Teori Equilibrium (BKKBN, 2007: 20) yaitu harus bekerjasama dalam kemitraan dan keharmonisan dalam kehidupan berkeluarga.

\section{Fase Bencana berdasarkan Siklus Harian}

Siklus keseharian di Dusun, peran laki-laki dalam berbagai aspek hampir dapat dilakukan oleh perempuan, hanya saja persentase yang melakukan berbeda. Di Dusun Serut terdapat kelompok tani yang digerakkan oleh kaum laki-laki saja, dan terdapat kelompok perempuan tani. Kegiatan pertanian untuk menambah pendapatan keluarga, dengan kegiatan beragam mulai dari pembibitan sayuran, pembudidayaan jamur tiram, serta penanaman, dan pengolahan markisa.

Organisasi tani, bagi para laki-laki maupun perempuan berguna untuk mengembangkan potensinya, sejalan dengan meningkatkan perekonomian anggotanya. Pembahasan permasalahan di lapangan pada kegiatan pertanian dalam kelompok tani perempuan maupun laki-laki biasanya rutin dilakukan pada malam hari ketika sudah tidak ada kegiatan yang berhubungan dengan pekerjaan maupun aktivitas rumah tangga.
Pada malam hari, $10 \%$ sampel perempuan maupun laki-laki meluangkan waktu melakukan aktivitas lain. Menurut responden pertemuan rutin seluruh anggota kelompok tani dilakukan di tempat masing-masing anggota secara bergilir. Beribadah bersama merupakan salah satu kegiatan yang diagendakan oleh masing-masing kelompok tani guna memupuk rasa persaudaraan yang bernuansa religi. Kegiatan yang berkaitan dengan beribadah bersama ini semakin rutin dilaksanakan pasca bencana gempabumi Bantul tahun 2006. Kondisi ini mempercepat pemulihan kembali rehabilitasi korban pascabencana (Ruslanjari, 2010:699).

Perbedaan utama antara Dusun Serut dan Dusun Padasan adalah di Dusun Padasan kaum laki-laki tidak melakukan pekerjaan rumah tangga, sementara di Dusun Serut masih terdapat laki-laki yang melakukan perkerjaan rumah tangga. Karakteristik rumah tangga dipengaruhi oleh kondisi sosial masyarakat. Di Dusun Padasan masih ada perempuan yang di rumah saja mengurus keluarga dan rumah tangga. Di Dusun Serut tidak ada ibu rumah tangga yang tidak bekerja.

Aktivitas di bidang pertanian sedikit berbeda antara masyarakat tani di Dusun Serut dengan di Dusun Padasan. Masyarakat tani di Dusun Padasan tidak bisa segera melakukan aktivitas bertaninya dikarenakan debu vulkanis hasil erupsi Gunung Merapi masih berdampak panas pada lahan pertanian. Menurut responden, debu Merapi kondisi ini menghentikan kegiatan bertaninya dalam kurun waktu yang cukup lama, menunggu hingga lahan dapat diolah kembali. Hasil wawancara mendalam dengan responden di Dusun Serut menyatakan bahwa untuk kegiatan kelompok tani kaum laki-laki lebih baik daripada kaum perempuan. Hal ini dikarenakan keterbatasan dukungan dana dari pemerintah, serta kegiatan pemberdayaan kelompok tani untuk kaum perempuan baru akan dilangsungkan pada tahun berikutnya, sehingga kegiatan di malam hari bagi perempuan, dihabiskan bersama keluarga di rumah. 
Dalam hal bencana, perempuan jarang mendapatkan akses langsung atau kontrol untuk mengelola sumberdaya (Karami dan Mansoorabadi, 2008: 884). Pernyataan ini didukung pula dengan data siklus harian perempuan, di mana perempuan yang memiliki kodrat utama sebagai ibu rumah tangga banyak menghabiskan waktunya di rumah terkait kegiatan rumah tangga. Siklus harian perempuan tersebut sesuai dengan pernyataan Barker dan Pawlak (2011: 11) yang menyebutkan bahwa perempuan diharapkan untuk menyediakan perawatan terhadap aspek reproduksi dan sesuai dengan pernyataan Cinamon dan Rich (2002: 532) yang menyebutkan bahwa perempuan juga mempunyai tanggung jawab terhadap keadaan rumah. Apabila terjadi kasus bencana, maka perempuan lebih banyak yang terkena adalah kaum perempuan. Disayangkan bawaha data korban gempabumi Bantul belum memisahkan antara jumlah korban perempuan dan jumlah korban laki-laki.

\section{Fase Tanggap Darurat berdasarkan Peran Gender}

Pada fase tanggap darurat baik perempuan maupun laki-laki di Dusun Serut memiliki aktivitas utama yang dilakukan, yakni menyelamatkan diri. Penyelamatan diri sendiri didasari bahwa kejadian gempabumi yang terjadi pada pagi Sabtu jam 6 pagi, sehingga sebagian anak sudah berangkat ke sekolah, sedangkan para ibu sebagian besar berada di dalam rumah, aktivitas di dapur, dan lainnya. Responden dominan menyelamatkan diri sendiri. Persentase tertinggi baik lakilaki dan perempuan terdapat pada poin menyelamatkan diri dan lebih memilih tinggal di posko pengungsian yang disediakan oleh pemerintah.

Pilihan tersebut didasari oleh anggapan bahwa hampir dari separuh responden masih merasa takut akan terjadi gempa susulan yang dasyat. Di samping itu, hasil wawancara dengan beberapa reponden menjelaskan bahwa banyak dari mereka yang rumah huniannya mengalami kerusakan yang cukup parah, sehingga harus memilih untuk mengungsi di posko pengungsian. Sebagian kecil membuat huntara darurat sendiri atau memilih tinggal bersama sanak saudara di luar kota.

Masyarakat tani di Dusun Padasan di mana pada fase tanggap darurat letusan Gunung Merapi yang dominan dari mereka adalah lebih memilih untuk menyelamatkan diri serta keluarga dan mengungsi di posko. Hal ini didasarkan telah adanya pemberitahuan sebelumnya akan adanya letusan (early warning system) dari pemerintah mengenai status siaga dari bencana erupsi Gunung Merapi. Kondisi ini mengakibatkan masyarakat dapat dengan mudah untuk segera dikoordinir guna proses evakuasi.

\section{Fase Pascsabencana berdasarkan Peran Gender}

Pada fase pascabencana baik di Dusun Serut maupun Dusun Padasan, hampir seluruh masyarakat lebih memilih untuk fokus dengan upaya pemulihan sosial ekonomi pasca bencana. EUROSTEP (1995) dalam Delaney, et. al. (2000: 15) menyebutkan bahwa lak-laki dan perempuan mempunyai perbedaan kebutuhan dan prioritas akibat dari bencana. Laki-laki terfokus pada aktivitas produksi, termasuk di dalamnya adalah pertanian dan pendapatan. Wanita memprioritaskan pada kesehatan fisik dan psikologis, kesempatan mendapatkan penghasilan, dan kesejahteraan anak-anaknya.

Banyak hal yang dilakukan baik oleh laki-laki maupun perempuan dalam rangka pemulihan sosial ekonomi dengan kembali di bidang pertanian maupun bekerja di luar sektor pertanian. Semangat dalam membangun kembali perekonomian keluarga, terbukti di Dusun Serut dan Dusun Padasan yaitu muncul pekerjaan-pekerjaan baru pascabencana yang justru dapat memberikan pemasukan pada perekonomian mereka, dan pekerjaan yang menjadi pilihan utama adalah menjadi buruh bangunan.

Tidak hanya laki-laki, tetapi perempuan di Dusun Serut juga turut memanfaatkan situasi pasca bencana guna berprofesi sebagai pegawai bangunan bayaran yang turut membantu upaya rehabilitasi dan rekonstruksi yang dilakukan oleh pemerintah. Salah satu 
responden mengaku upah yang didapatkan dalam satu hari kerja dapat berkisar antara Rp30.000,00 hingga Rp50.000,00 tergantung pada jenis pekerjaan.

Peran gender dalam bencana baik pada siklus manajemen bencana di kedua dusun tersebut, masing-masing individu baik perempuan maupun pria seyogyanya memiliki kesempatan yang sama, hanya saja perlu ada penanganan yang khusus pada kaum perempuan karena perempuan tetap terpinggirkan dalam proses perkembangannya, meskipun masalah gender dalam kontek perkembangan sedang dalam penelitian dan perdebatan (UNISDR, 2009: 4).

Kasus peran gender di Dusun Serut dan di Dusun Padasan dapat dijadikan pembelajaran. Aktivitas perempuan pada daerah rawan bencana bukan saja berkutat pada urusan rumah tangga saja. Pembentukan organisasi perempuan seperti yang sudah terlaksana di Dusun Serut yakni kelompok Perempuan Tani Harapan Subur di mana aktivitas perempuan tani benar-benar diberi wadah dan sebagai sarana gotong royong. Dalam menunjang kegiatan tersebut, tentunya tidak terlepas dari dukungan berbagai pihak seperti Pemda maupun pihak-pihak lain yang terkait. Di Dusun Padasan kelompok tani perempuan merupakan organisasi baru yang bergabung dengan kelompok tani para laki-laki.

\section{SIMPULAN}

Simpulan dari penelitian ini, yaitu sebagai berikut. Pertama, Adanya kesamaan peran dan perbedaan aset kerja antara laki-laki dan perempuan di Dusun Serut dengan Dusun Padasan yang mempunyai bencana berbeda pada siklus manajemen bencana.

Kedua, Adanya kesamaan persentase peran laki-laki di Dusun Serut dan di Dusun Padasan, yakni 96,67\% laki-laki mempunyai peran tunggal yakni berkerja dan ada 3,33\% lakilaki memiliki peran ganda, yakni bekerja dan melakukan pekerjaan rumah tangga. Adanya perbedaan persentase peran perempuan, yakni, perempuan di Dusun Serut 16,67\% mempunyai peran tunggal yakni hanya menjadi ibu rumah tangga saja dan $83,33 \%$ memiliki peran ganda yakni bekerja dan menjadi ibu rumah tangga, dan perempuan di Dusun Padasan, 13,33\% perempuan mempunyai peran tunggal dan $86,67 \%$ memiliki peran ganda. Hal tersebut diatas akan ditunjukkan pada Tabel 4.

Tabel 4. Persentase Peran Laki-Laki dan Perempuan dalam Rumah Tangga

\begin{tabular}{l|l|l|l|l}
\hline & \multicolumn{3}{|l|}{ Dusun Serut } & Dusun Padasan \\
\cline { 2 - 5 } & Peran Tunggal & Peran Ganda & Peran Tunggal & Peran Ganda \\
\hline Laki-laki & $96,67 \%$ & $3,33 \%$ & $96,67 \%$ & $3,33 \%$ \\
\hline Perempuan & $16,67 \%$ & $83,33 \%$ & $13,33 \%$ & $86,67 \%$ \\
\hline
\end{tabular}

Ketiga,Variabel umur, pendidikan dan penghasilan tidak berpengaruh terhadap peran perempuan dalam bencana gempabumi di Dusun Serut dan bencana letusan gunung api di Dusun Padasan.

\section{DAFTAR PUSTAKA}

Alston, Margaret. 2013. Research, Action dan Policy: Addressing the Gendered Impacts of Climate Change. Springer Science+Business Media Dordrecht 2013. DOI 10.1007/978-94-007-55185.
BAPPENAS.2006. Penilaian Awal Kerusakan dan Kerugian Bencana Alam di Yogyakarta dan Jawa Tengah. Jakarta: BAPPENAS.

Barker, Gary dan Piotr "Peter" Pawlak. 2011. Men, Families, Gender Equality dan Care Work. Dalam Men in Families dan Family Policy in a Changing World. New York: the United Nations. ISBN 978-92-1-130306-3.

BKKBN - Pusat Pelatihan Gender dan Peningkatan Kualitas Perempuan. 2007. Konsep dan Teori Gender. 
Jakarta: Badan Koordinasi Keluarga Berencana Nasional.

Cinamon, Rachel Gali, dan Yisrael Rich. 2002. "Gender Differences in the Importance of Work dan Family Roles: Implications for Work-Family Conflict." Sex Roles 47 (11-12): 53141. doi:10.1023/ A:1022021804846.

Delaney, Patricia L. dan Elizabeth Shrader. 2000. "Gender dan Post-Disaster Reconstruction: The Case of Hurricane Mitch in Honduras dan Nicaragua." The World Bank.

Elizabeth, Roosganda. 2008. Peran Ganda Perempuan Tani dalam Mencapai Ketahanan Pangan. Jurnal dimuat dalam Pusat Analisis Sosial Ekonomi dan Kebijakan Pertanian.

Enarson, E, A Fothergill, dan L Peek. 2007. "Gender dan Disater: Foundations dan Directions." Hdanbook of Disaster Research, 130-46.

Fatimah, Dati. 2010. Gender Mainstreaming dalam Pengurangan Risiko Bencana. Yogyakarta: Aksara.

Fischer, Elisabeth, dan Matin Qaim. 2012. "Gender, Agricultural Commercialization, dan Collective Action in Kenya." Food Security 4 (3): 441-53. doi:10.1007/s12571-0120199-7.

Karami, Ezatollah, dan Afsaneh Mansoorabadi. 2008. "Sustainable Agricultural Attitudes dan Behaviors: A Gender Analysis of Iranian Farmers." Environment, Development dan Sustainability 10 (6): 883-98. doi:10.1007/s10668-007-9090-7.

Muehlenhard, Charlene L., dan Zoe D. Peterson. 2011. "Distinguishing Between Sex dan Gender: History, Current Conceptualizations, dan Implications." Sex Roles 64 (11-12): 791-803. doi:10.1007/s11199-0119932-5.
Muhammad. 2015. “Tingkat Kesiapan Masyarakat Pengelolaan Lingkungan dan Kepariwisataan Alam Pasca Erupsi Merapi 2010". Jurnal Kawistara. Volume 5, Nomor 2, Agustus 2015. ISSN 2088-5415.

Partini, 2013, Bias Gender dalam Birokrasi, Yogyakarta: Tiara Wacana.

Picquout, A., F. Lavigne, E. T W Mei, D. Grancher, Cholik Noer, C. M. Vidal, dan D. S. Hadmoko. 2013. "Air Traffic Disturbance due to the 2010 Merapi Volcano Eruption." Journal of Volcanology dan Geothermal Research 261: 366-75. doi:10.1016/j. jvolgeores.2013.04.005.

Pryzgoda, Jayde, dan Joan C. Chrisler. 2000. "Definitions of Gender dan Sex : The Subtleties of Meaning." Sex Roles 43: 553-69. doi:10.1016/S08904065(00)80019-5.

Reyes, Daniella Dominique, dan Jinky Leilanie Lu. 2016. "Gender Dimension in Disaster Situations: A Case Study of Flood Prone Women in Malabon City, Metro Manila." International Journal of Disaster Risk Reduction 15. Elsevier: 162-68. doi:10.1016/j. ijdrr.2015.11.001.

Ruslanjari, D. 2010. “Peran Kearifan Lokal dalam Kecepatan rehabilitasi dan rekonstruksi Bencanagempabumi di Desa Multireligi dan Monoreligi Kasus di Kabupaten Bantul". Jurnal Kebencanaan. Volume 2, Nomor 3688703.

Ruslanjari, Dina; Ardina, Mega; dan Fathoni, M.A. 2013. "Kearifan Lokal pada Usahatani Organik Mendukung Ketahanan Pangan Keluarga di Dua Dusun di Yogyakakarta". Yogyakarta: Universitas Gadjah Mada.

Tong, Yan, Liangxin Fan, dan Haipeng Niu. 2016. "Water Conservation Awareness dan Practices in Households Receiving Improved 
Dina Ruslanjari -- Peran Gender Pada Siklus Manajemen Bencana di Sektor Sosial Ekonomi Rumah Tangga Tani (Bencana Alam Gempabumi dan Letusan Gunungapi)

Water Supply: A Gender-Based Analysis." Journal of Cleaner Production 141. Elsevier Ltd: 947-55. doi:10.1016/j.jclepro.2016.09.169.

United Nations International Strategy for Disaster Reduction (UNISDR). 2009.
The Disaster Risk Reduction Process : A Gender Perspective. Geneva: UNISDR. .2007. Undang- Undang Nomor 24 Tahun 2007 tentang Penanggulangan Bencana. Jakarta: BNPB. 